Rebecca Henn | Caldieron, Miller | Constance Bodurow Stallmeyer, Dearborn | Seth Wiley | Brian Szymanik

\section{Residential Satisfaction in the Informal Neighborhoods of Ulaanbaatar, Mongolia}

\author{
Jean Caldieron, Florida Atlantic University, School of \\ Architecture \\ Rick Miller, UCLA, Department of Geography
}

\begin{abstract}
Residential satisfaction is a very important factor in determining the quality of life, housing improvement proposals, and adequate housing policies. This paper reports on the findings of a study in four informal neighborhoods or "ger districts" of Ulaanbaatar, the Mongolian capital. Mongolia has been facing an onslaught of rural migration to the urban areas because of two reasons. First, rural nomads have lost their livestock due to recent harsh climate conditions, and second because of the transition from communism to a democratic market economy, based on the exploitation of Mongolia's rich mineral resources. In the cities, migrants have invaded land and erected rural nomadic "ger" (felt tents or yurts). The traditional ger (as they are called in the Mongolian language) are sustainable structures well adapted for a nomadic society. However, when they are located in high-density, unplanned shantytowns, they create many issues. The country's capital, Ulaanbaatar, is the coldest capital in the world; ger' household use coal for heating which causes dense air pollution, especially in the winter. These informal urban areas
\end{abstract}

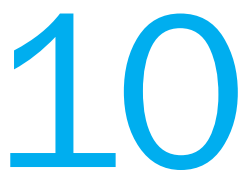

volume 7 | issue 1 lack sanitation, adequate vehicular access and other services. Eventually residents build small permanent houses, but they still lack for basic services. This paper presents the findings of more than one hundred household surveys related to housing conditions in three informal ger districts of Ulaanbaatar. The surveys were held in the summer of 2011. This paper discusses some of the characteristics of the settlements as well as the residential satisfaction of its inhabitants.

\section{Keywords:}

Ger districts, informal urban settlements, Mongolian slums, residential satisfaction, quality of self-built shelters.

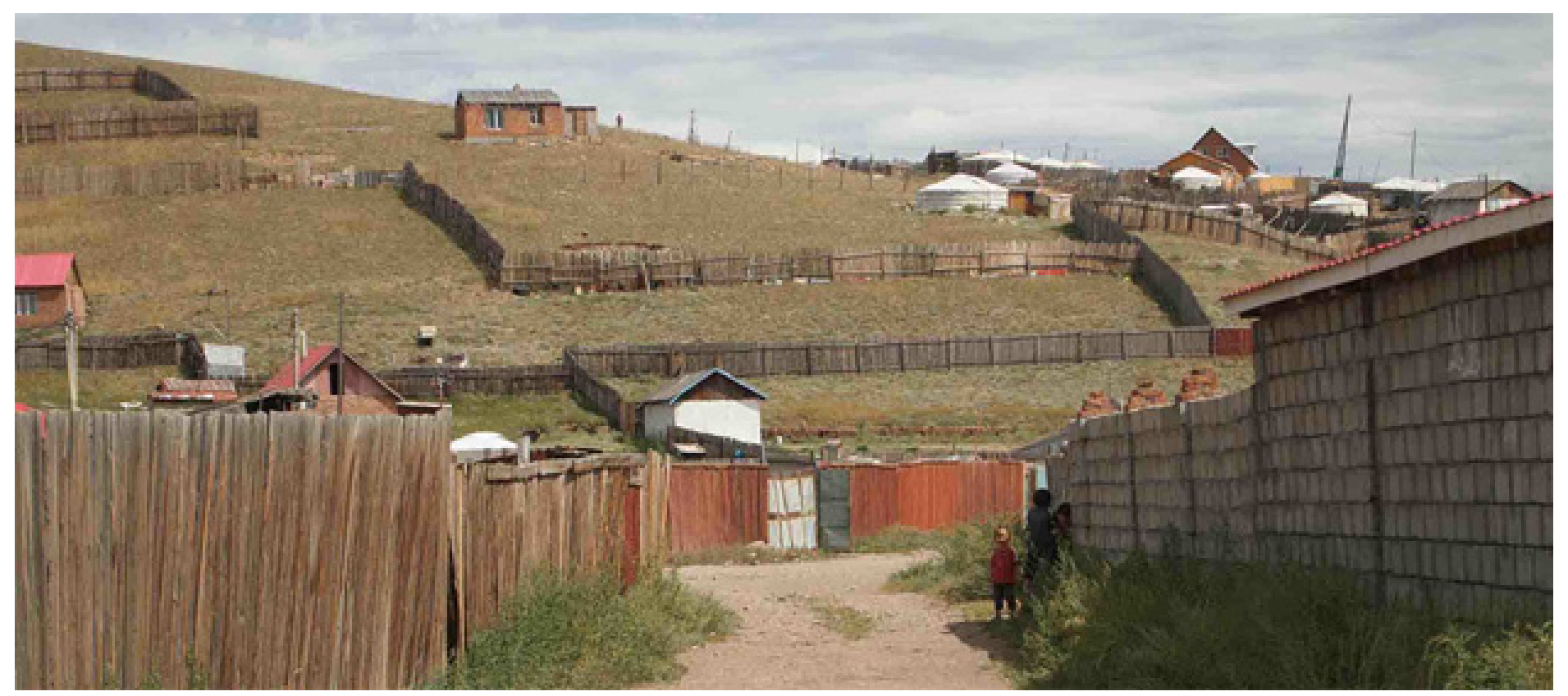

Figure 1: Ger and permanent dwellings in Uliastai, Ulaanbaatar. 


\section{Introduction}

Mongolia is experiencing a cultural transformation as globalization and urbanization are changing the country's traditional nomadic way of life. Major demographic shifts are raising the urbanization rate in cities such as Ulaanbaatar, the capital, which has grown, on average, more than eleven percent a year in the past twenty years.

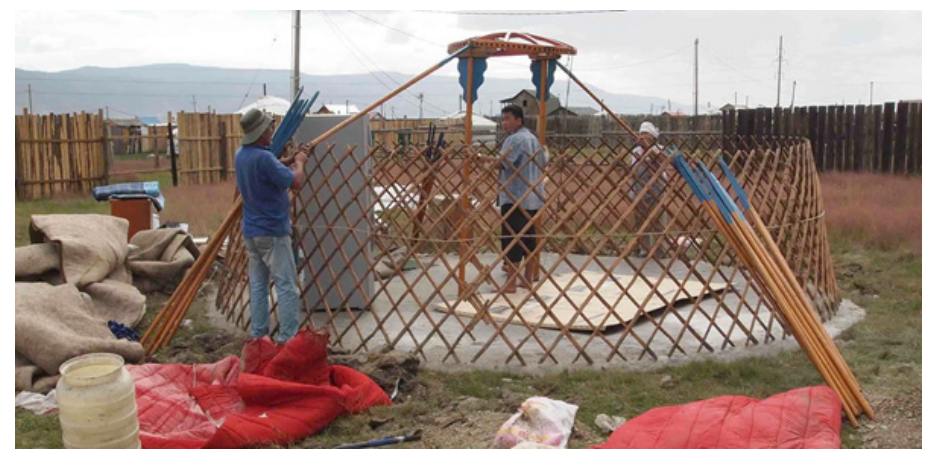

Figure 2: Building a "ger" in Ulaanbaatar

Until recently, Mongolia had a predominantly nomad population. The Soviet directed economy established industries and built Soviet-style apartments for thousands of families. While this increased the urban population, the working opportunities were still restricted due to rural migration control. Today, with the arrival of democracy, a market-oriented economy, and the recent mineral boom, thousands of rural Mongolians are starting to move to the capital. Ulaanbaatar, with less than $0.3 \%$ of the total land area of the country already hosts $45 \%$ of its population. The economic boom has increased the price of formal residential properties in a country, which is mostly composed of Soviet-era apartment complexes. Land use and the urban planning in the city are changing rapidly. (Gombodorj 2004, Gotov 2010).

There is an increase of commercial activities in the city center, expansion of urbanized areas and a strong growth of informal ger settlements. (Badamdorj 2004) All this growth has many consequences such as an increase in air pollution. (Guttikunda 2008.)

Most urban poor in Ulaanbaatar (many of whom were nomads), have no other alternative but to live in traditional "ger" when they migrate to the city. "Ger" are the same traditional felt tent dwellings they used in the countryside. Over time ger are usually replaced with dwellings made of enduring materials although many of them still lack services such as a fresh water supply and wastewater sewerage (Figure 1).

Ger, (also called yurt in Russian) are round felt tents. Felt tents are a common housing type among nomads in many Central Asian countries from Turkey to China. (Andrews 1992) Mongolian ger are composed of a primary structure of two central columns encircled by a lattice wall. The columns and wall support a series of beams that form a circular roof. Wires around the walls secure the structure (Figure 2).
At the top of the structure thick felt acts as an extraordinary insulating material. Finally, an impermeable plastic layer and a traditional white cotton fabric complete the ensemble. A ger can be built in a couple of hours by a group of four people and have been recognized as a very suitable shelter for nomads (Figure 3 ). The structures are adaptable to the changing climatic conditions of continental countries, where summers can be hot and winters extremely cold. They are portable and structurally strong, resisting the winds of the Steppes. Nomadic life using ger as a shelter can be very sustainable in the rural areas of Mongolia. Because of the small quantity of ger built in a given location, the ecological impact is quite small. Mongolians have a strong tradition of respecting nature. Unfortunately, when ger form high-density districts, the impact can be negative. Urban ger in Mongolia are built without an existing urban plan or the installation of services. As a result, extensive informal communities have appeared in the last few years.

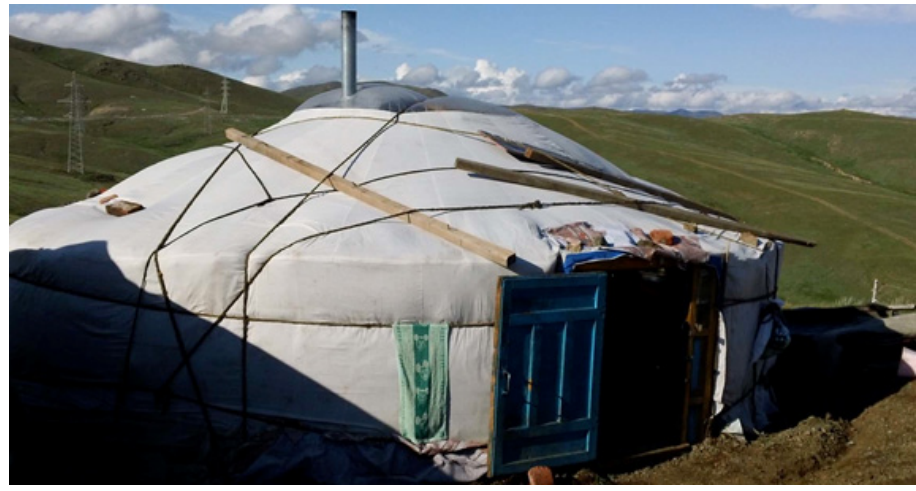

Figure 3: Traditional "ger"

Despite the fact that in most countries informal settlements are illegal because land is invaded without documentation, some informal settlements can be successful. Extensive research shows that the formal construction market and new social houses are incapable of satisfying the rising demands for housing (Turner 1970, Costa 1997). Ger settlements have been studied in rural areas of Mongolia. Most of the studies related to gender distribution in the gers (Park 1999) internal environment (Janzen 2002).

Ger settlements can be successful in rural areas if sanitary conditions and environmental sustainability conditions are met, but this is difficult in urban areas. However, the success of a dwelling depends not only on how effectively the building provides the setting for activities of daily living but also on the perceptions of its residents (Potter 2001).

Residential satisfaction is fundamental to identifying the quality of life of settlers and it should be taken into account when designing housing and planning urban policies. Some settlers feel satisfied with their dwelling independent of the opinion of researchers and professionals. In other words, the researchers may feel the quality of the environment is not compatible, which contrasts the view of the settlers. Residential 
satisfaction has been studied in a wide variety of housing settings. Examples are the comparative studies of renovated buildings (Potter 2001) and others.

However, residential satisfaction in developing countries, especially in slums, has not been popular among researchers. The pioneer studies, realized by Fried and Gleicher (1971), Aragones and Corraliza (1992), Amerigo and Aragones (1997) and recent studies of Caldieron (2011), explain how the satisfaction in slums relate with positive relations among neighbors and the individual pride of a self-built dwelling.

In the case of Ulaanbaatar, the only published researches that have some relation with residential satisfaction are concentrated on the resident's

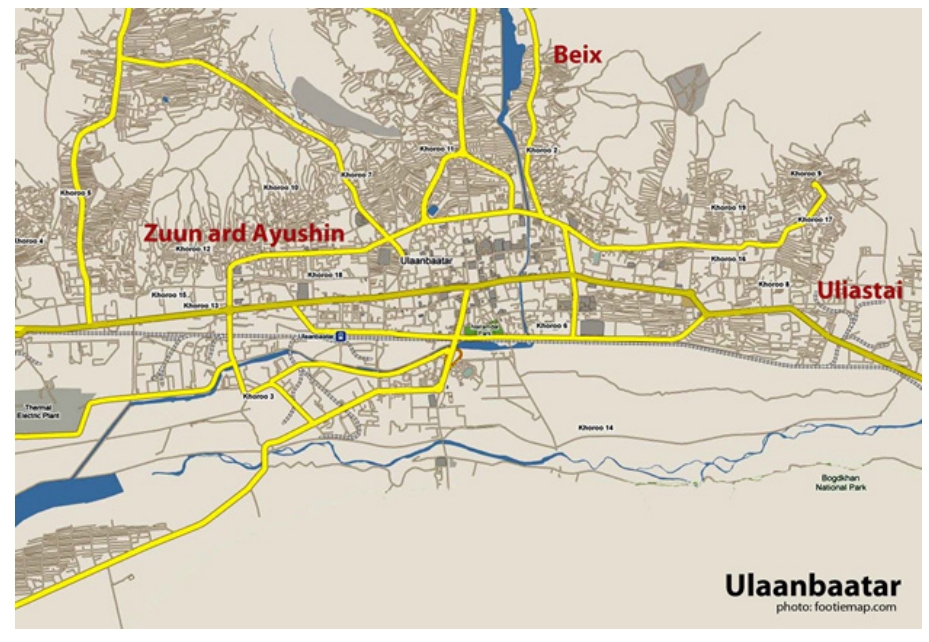

Figure 4: Location of the selected ger districts.

perception of living space and lifestyle in residential apartment complexes or in the countryside areas (Kawagishi, 2005 and 2010, Hazegawa 2004). There are no studies, until now, of residential satisfaction in ger districts in Ulaanbaatar. Therefore, because the satisfaction of the user of a dwelling is important, and no previous research exist in Mongolia ger, this study of residential satisfaction in Ulaanbaatar is justified.

\section{Methodology}

For this research three representative ger-districts in the capital were selected. The first is Zuun ard Ayushin, which is a relatively consolidated area with relatively good roads, located near the city core. The other representative districts are Beix and Uliastai. Each one of them is located in a different peripheral area of the city's boundaries and is not consolidated yet (Figure 4).

A questionnaire consisting of thirty-three questions was given in about one hundred and twelve households located in the three different ger districts. The data was collected in the summer of 2011. Mongolia has a high literacy rate of $98.5 \%$ according to the last National Census; therefore, it was possible to use a questionnaire written in the Mongolian Language for this research. The participating households either answered the questionnaires immediately or were given the option to return the survey later the same day. The survey covered a wide range of sociocultural aspects related with the dwellings. This paper only included the questions related with the length of time of residence, characteristics of the dwellings, intentions to move, and satisfaction with the dwellings and neighborhood. In many of the plots, more than one ger or dwelling is built. If a nuclear family occupies a specific plot of land (regardless of how many dwellings), then only one questionnaire was distributed. When several family groups occupy the same plot of land, each dwelling will answer a different questionnaire.

\section{Hypothesis}

The hypothesis of this study is that householders are satisfied with their shelter mainly if two conditions are present:

1. The dwellings have sanitary installations.

2. The dwellings are located near the main roads.

\section{Results}

This paper is based on the survey's responses of which $97 \%$ of the questionnaires distributed were successfully recollected. In some of the cases the questions were formulated to allow the respondents to choose more than one answer.

Householder Mobility Approximately $48 \%$ of the ger district householders were living as nomads in the countryside before moving to their present domicile (Table 1). Therefore, half of the selected householders did not live on the site or in any other city before moving to the capital. It is appropriate to remember that this country, which once was a nomadic rural society, is transforming into a highly urbanized society. The migration from countryside to cities is a typical phenomenon in many developing countries, but in most of them, countryside settlers were not nomadic. In Mongolia urban migrants are nomads and the traditional nomadic dwellings are translated to the city.

\begin{tabular}{|c|c|}
\hline $\begin{array}{c}\text { Householder was a nomad before } \\
\text { moving to the present location? }\end{array}$ & $\%$ \\
\hline Yes & 48 \\
No & 52 \\
\hline
\end{tabular}

Table 1: Percentage of householders that were nomads before moving to their present location

In order to understand the population mobility in the selected ger districts, the householders were asked how long ago they arrived at the selected plot of land. Table 2, shows how $18 \%$ of those polled had been in their present location for less than one year and $57 \%$ had been there less than five years. Only $14 \%$ have lived in their present place for more than ten years. 
If nearly $50 \%$ of the population was nomadic before moving to the present location and $57 \%$ have been living in the place for less than five years, one can infer from these findings that the selected neighborhoods have been growing very fast.

\begin{tabular}{|c|c|}
\hline Time living in the present plot of land & $\begin{array}{c}\text { Households } \\
\text { (\%) }\end{array}$ \\
\hline Less than 1 year & 18 \\
Between 1 to 2 years & 12 \\
Between 3 to 5 years & 27 \\
Between 5 to 10 years & 29 \\
Between 10 to 20 years & 12 \\
More than 20 years & 2 \\
\hline
\end{tabular}

Table 2: Householder mobility; time living on the current plot of land

Land Tenure:

It is widely known that land tenure is an important factor to improve the self-built dwellings of low-income inhabitants. The land tenure situation of Mongolia is completely different from other developing countries. Since antiquity Mongolia has been a pastoral society. Traditionally the state has possession of the land, and as such, the land is for the common use of their inhabitants. However, since 2002, every Mongolian citizen is entitled to a one-time plot of land for free. The dimension of the plot depends of the place where it is located, (smaller in the big cities, larger in the countryside). This is a completely different situation compared to other developing countries. Mongolia with its low population density and can afford to provide a free piece of land to each one of its inhabitants. This situation explains how an impressive $79 \%$ of the householders taking part in this study are owners of the plot were they live (Table 3). This is especially remarkable when considering that most of the ger districts inhabitants are mostly new arrivals.

\begin{tabular}{|c|c|}
\hline Land tenure of the dwelling & $\%$ \\
\hline Own land, the householder has documents & 79 \\
Rented land & 12 \\
Invaded land or free use & 9 \\
\hline
\end{tabular}

Table 3: Status of householder's land tenure

Families living in ger without land tenure represent less than $9 \%$ of the total poll of this study. Most are new arrivals that are possibly just waiting to legalize their situation. This situation is very different compared to other developing countries where self-built informal neighborhoods and slums are initially built on invaded land; in these situations, the settlers are illegal "owners" whereas they have "perceived" land tenure. In many developing countries, legitimate land tenure for the urban low-income class is a very challenging achievement.
Residential dwelling satisfaction:

One of the main objectives of this paper is to determine the residential satisfaction of the householders with their dwelling. The results (Table 4) show that $35 \%$ of the householders are satisfied or very satisfied with their dwelling. About one third ( $29 \%$ percent) are unsatisfied or very unsatisfied. Finally $33 \%$ are in the middle, stating average satisfaction. Although many of the settlers feel satisfied, even if services are not incorporated into their dwellings. Most of the very unsatisfied settlers do not have latrines, are living in new areas of the ger districts that are not well located and are a long distance from public transportation. Usually, in these areas, there are no real streets and no sanitary services. When settlers are asked if they like their neighborhood (Table 5), $69 \%$ of them express residential satisfaction with the location.

\begin{tabular}{|c|c|}
\hline Are you satisfied with your dwelling? & $\begin{array}{c}\text { Households } \\
(\%)\end{array}$ \\
\hline Very satisfied & 11 \\
Satisfied & 24 \\
Average satisfaction & 33 \\
Unsatisfied & 20 \\
Very unsatisfied & 9 \\
No answer & 3 \\
\hline
\end{tabular}

Table 4: Residential satisfaction with the dwelling

\begin{tabular}{|c|c|}
\hline Do you like this neighborhood? & $\begin{array}{c}\text { Households } \\
(\%)\end{array}$ \\
\hline Yes & 69 \\
No & 23 \\
No answer & 9 \\
\hline
\end{tabular}

Table 5: Residential satisfaction with the neighborhood

Intention to Move:

A key question in this research is related to how permanent or provisional the traditional ger are in Ulaanbaatar. The first point is the likelihood that the inhabitants may move from the neighborhood. When asking if the householder wants to move from a ger district, about half of them answered positively. That means many of them are not satisfied with living in their current circumstances (Table 6). This number is quite high when compared with other informal neighborhoods around the world studied by the principal author. The main reason why the householders want to move is because they live in a ger. (not in a permanent dwelling). However, this reason only represents $12 \%$ of the answers. Some of the ger district householders want to move even if they live in an adequate dwelling of wood or brick. 
When settlers are asked if they want to move to an apartment, $61 \%$ answer positively (Table 7). In Mongolia, it is said that rich people live in apartments and low-income people live in ger or houses. Taking into account that most of Ulaanbaatar apartments are Soviet-style social housing, we can recognize that Mongolia presents a unique social situation that is unlike any other in the world. Soviet-style apartments are considered low-income housing in other places, but in Mongolia, many high-income people live in them.

Suitable changes in the dwelling and adequacy of the dwelling: When the households were asked what kind of changes they would like to do in their dwellings, $43 \%$ of them would like to replace the ger with a permanent dwelling; $8 \%$ of households suggested no changes because they would rather move (Table 8). This figure is much higher than in most other slums worldwide.

\begin{tabular}{|c|c|}
\hline Would you like to move from here? & $\begin{array}{c}\text { Households } \\
\text { (\%) }\end{array}$ \\
\hline No & 44.3 \\
Yes, reason not given & 13 \\
Yes, because I live in a ger & 10.4 \\
Yes, because the location is bad & 4 \\
Yes, deficient water/electricity supply & 4 \\
Yes, because of the pollution in winter & 4 \\
Yes, for other reasons & 8 \\
Unknown & 14 \\
\hline
\end{tabular}

Table 6: Householder's intention to relocate

Possibly, one of the reasons for the interest in moving is the lack of services. Traditional ger do not have interior plumbing or sanitary services. This situation may have been acceptable when living as a nomad, but it is complicated when living in an urban setting. Only $17 \%$ of the households participating in this study are connected to sewers, and about $36 \%$ do not have latrine facilities. As shown in table 9, 57\% of householders believe their houses are appropriate for their families.

\begin{tabular}{|c|c|}
\hline Would you like to move to an apartment? & $\%$ \\
\hline Yes & 61 \\
Don't know & 10 \\
No & 29 \\
\hline
\end{tabular}

Table 7: Householder intention to move to an apartment
It is widely known that when settlers self-build their houses they are usually more satisfied with the dwellings. In the case of the neighborhoods visited, most of the settlers self-built their houses. However, the level of satisfaction in this study in Ulaanbaatar is not as high as in other informal settlements in Latin America surveyed by the author. Most of the unsatisfied inhabitants were living in ger tents without sanitation services. This research is a pilot study that may allow for future research and comparison among different neighborhoods.

\begin{tabular}{|c|c|}
\hline Suitable changes in your dwelling & $\begin{array}{c}\text { Household } \\
(\%)\end{array}$ \\
\hline No changes, I want to move. & 8 \\
Replace a ger with a permanent dwelling & 43 \\
Improve the services & 30 \\
Other & 19 \\
\hline
\end{tabular}

Table 8: Suitable changes in the dwelling

\begin{tabular}{|c|c|}
\hline $\begin{array}{c}\text { Do you believe this house is } \\
\text { appropriate for your family? }\end{array}$ & $\%$ \\
\hline Yes & 57 \\
No & 33 \\
No answer & 10 \\
\hline
\end{tabular}

Table 9: Householder's opinions: The dwelling is appropriate?

\section{Conclusions}

There is no doubt Mongolia is facing a challenging urban population growth which is reflected in new ger districts in cities such as Ulaanbaatar. The recent exploitation of mineral resources and the growing foreign investment in Mongolia are transforming this nomadic society. The growth of Ulaanbaatar and its ger districts is expected to continue for a long time. The conditions and nature of the slums and self-built informal settlements of Ulaanbaatar are very different compared with other developing countries. In other countries, informal settlements are part of the invasions of public and private land. In Mongolia, all inhabitants have the possibility to receive free land from the government; tenure is not a main issue. A second difference is the type of housing. Usually migrants move to Ulaanbaatar with their belonging, which includes the ger (felt tents). They usually do not use recycled materials to build a shack (as in many countries). Mongolian ger are a traditional dwelling well adapted to the climate; they are a product of hundreds of years of popular knowledge.

Ger are well adapted to a nomadic culture and way of life, but their presence is problematic in an urban setting. One of the main challenges of ger districts is the incorporation of sanitary services to each residence. 
In the countryside the ger are movable and the rural low density allows their inhabitants to accept the lack of internal sanitary services. In an urban ger, inhabitants usually build latrines; a high density of latrines within a short proximity can pollute water resources. Among other differences and challenges, the provisional nature of the ger clashes with the permanent nature of urban housing.

This research is composed of a small amount of data collected in a limited number of communities. However the hypothesis of the research seems to be accurate. Householders are satisfied with their shelter.

The data also shows us that ger communities are improving. Most of the householders who transformed their ger were able to build permanent residences using concrete, wood or bricks. The question is, are the urban ger provisional dwellings? The survey shows that many of the householders are likely to move out of the ger either to a new location or a more permanent dwelling. According to this research, it is likely that permanent dwellings will substitute urban ger. Yet, it is a shame that such a rich example of vernacular architecture may only be permissible in the countryside.

The Mongolian government and investors are getting serious about the exploitation of the rich mineral resources of the country. Also, the GDP of the country is rising rapidly. The modern exploration of mineral resources has just scratched the surface, but, as many people suggest, Mongolia may be the next Dubai for better and for worse. One of the most dangerous consequences of such a rapid development could be ecological damage. During the winter, Ulaanbaatar is a heavily polluted city because of the use of fossil fuels (coal) for energy needs. The demand of resources by Mongolian cities could damage not only its traditional vernacular architecture but also the pristine nature of the country.

\section{Bibliography:}

Amérigo, Maria, Aragones, Juan. (1997)A theoretical and methodological approach to the study of residential satisfaction. Journal of Environmental Psychology. Volume 17, Issue 1. Pages 47-57.

Andrews, P. A. (1992) "The White House of Khurasan: The Felt Tents of the Iranian Yomut and Gökleñ Iran” Vol. 11 pp. 93-110 (1973).

Aragonés, Juan; Corraliza, José. 1992. Satisfacción residencial en ámbitos de infravivienda. Psicothema 4: 329-341.

Caldieron, Jean. 2011. Residential Satisfaction in La Perla Informal Neighbourhood, San Juan, Puerto Rico. Oida International Journal of Sustainable Development, Vol. 2 N. 11, pp 77-84.

Badamdorj, Chinbat. 2004. Changes in the internal structure of Ulaanbaatar, Mongolia. Scientific Annual of Korea Mongolian Economic Association v.14: pp.1-16.

Choi, Choongik. 2012. Inexorable rise of ger in Mongolia: demolition for redevelopment or conservation for improvement? International Review of Public Administration v.17, n.2: pp.121-41.
Costa, M. 1997. Self-help approaches to the provision of Housing: The long debate and a Few Lessons. Cities in the Developing World. Edit by J. Gugler Oxford University Pr. (1997).

Fried, Mark ; Gleicher, Peggy. 1961. Some resources of residential Satisfaction in Slums. Journal of the American Institute of Planners.

Gombodorj, Gatulga ; Badamdorj, Chinbat. 2004. On a new land use classification and zoning scheme of Ulaanbaatar, Mongolia. Journal of Social Science, Soonchunghyang University v.10, n.1: pp.1-30.

Gotov, Narangerel. 2010. The Ulaanbaatar city urban planning policy and UB city Master Plan up to 2020, Urban Planning, Research and Design Institute, Ulaanbaatar.

Guttikunda, S. Urban Air Pollution Analysis for Ulaanbaatar, Mongolia. 2008. SIM Working Paper No. 2008-005. h http://ssrn.com/ abstract=1288328. (2008).

Hasegawa, Mitsuhiro, Umekazu Kawagishi, Ishjamts Gonchigbat, and Takumi Nakanishi. 2004. "Study of the living space planning in Ulaanbaatar, Mongolia." Journal of Asian Architecture and Building Engineering v.3, n.1.

Janzen, Joerg, and Gereltsetseg D. 2002. "A new ger-settlement in Ulaanbaatar: functional differentiation, demographic and socioeconomic structure and origin of residents; an example from 2nd khoroo of Bayanzurkh Duureg, west of Dari Ekh ovoo; as in June 2002." National University of Mongolia, Center for Development Research, Ulaanbaatar. Kato, Jun, Purev-Erdene Ershuu, and Shohei Ishikawa. unpublished 2007. "Results of a survey into the internal environment of Ulaanbaatar's ger area household." conf. The current situation of ger area in Ulaanbaatar city.

Kawagishi, Umekakazu, Ishii, Susumu; Yoshimishi, Tsuboi, Noboru, Yuasa, Kazuo, Utsugi, Ishjamts, Gonchigbat, Batbold, Badrakh, Hasegawa, Mitsuhiro. 2005. Study of the living space planning in Ulaanbaatar Mongolia Part 2 Residential and Living environment in Apartments complexes. Journal of Asian Architecture and Building Engineering. Vol. 4 N. 1 Page 151-159.

Kawagishi, Umekazu, Hirofumi Sugimoto, Koki Kitano, Ishjamts Gonchigbat, and Naoyuki Hirota. 2010. Living environment of nomads residing on the outskirts of Ulaanbaatar, Mongolia part 2. Journal of Asian Architecture and Building Engineering v.9, n.1.

Kawagishi, Umekazu, Susumu Ishii, Yoshimichi Tsuboi, Noboru Yuasa, Kazuo Usugi, Ishjamts Gonchigbat, Badrakh Batbold, Koki Kitano, and Hirofumi Sugimoto. 2005. Study of the living space planning in Ulaanbaatar, Mongolia part 3. Journal of Asian Architecture and Building Engineering v.4, n.2.

Marois, A. 2006. D'un habitat mobile à un habitat fixe. Fondements et changements de l'orientation dans l'espace domestique mongol. Études mongoles et sibériennes, centrasiatiques et tibétaines p. 207-237.

Park H. Y. and Arioti M. 1999. Lo spazio domestico: La tenda (ger) come centro delle relazioni sociali e di genere nella Mongolia post socialista. La Ricerca Folklorica, No. 40, Società pastorali d'Africa e d'Asia pp. 47. 
Potter, James; Chocoine, Lincoln; Speicher, Katryn. 2001. Predicting Residential Satisfaction: A comparative case of Study. Architectural Programs at Digital Commons University of Nebrasca - Lincoln Sugimoto, Hirofumi, Kawagishi, Umekatsu, Koki Kitano, Ishjamts Gonchigbat, Naoyuki Hirota. 2007. Living Environment of Nomads Residing on the Outskirts of Ulaanbaatar, Mongolia -Dispositional Characteristics from the Perspective of a Comparison of Nomads and People Living in Ger Fixed Residences in the City -. Journal of Asian Architecture and Building Engineering, AIJ, AIK, ASC, vol.6 no.2, pp.283290.

Tseregmaa, Byambadorj, Marco Amati, and Kristian J. Ruming. 2011. "Twenty-first century nomadic city: ger districts and barriers to the implementation of the Ulaanbaatar City Master Plan." Asia Pacific Viewepoint v.52, ? 2: pp.165-77.

Turner, J. 1977. Housing the people, Towards autonomy in Buildings environment. New York Pantheon Books.

\section{Acknowledgements}

This research was partially supported through the US-Mongolia Field Research Fellowship Program, sponsored by the American Center for Mongolian Studies (ACMS), the Council of American Overseas Research Centers (CAORC), and the US Department of Education. 